\title{
Tempel Anneke's Confessions: Four Phases of Faith
}

\author{
Miranda Van Heyst
}

Historians have long sought to understand the reasoning and nature of the witch trials that spanned hundreds of years of European and American history. To conduct their research historians have turned to regional archives for their primary source documents. Primary sources such as witch trial documents provide a window into the past, which allows historians to gain an insight into what happened. In particular, historians have been able to question the role of gender, religion, and the validity of confessions through trial documents. Based off the primary source documents, historians have proposed a wide variety of theories to explain the confessions of victims that appeared in trial documents. For example, Virginia Krause came to the conclusion that demonologists used confessions as a self-legitimizing device, which in essence meant they forced the accused to confess to the demonological narrative they wanted to hear. ${ }^{1}$ It was through the confessions that demonological theory was validated, and in essence, as stated by Krause, "producing guilt and producing knowledge are thus inextricably tied together in demonological theory." Krause studied witch trial confessions and came to the conclusion that court officials and demonologists used confessions as a way to validate their narrative and beliefs of witchcraft.

In contrast to Krause, Louise Jackson explained that physical and psychological pressures played a role in women confessing to witchcraft, and some women also did truly believed they were working for the devil. ${ }^{3}$ Women accused of witchcraft principally were judging themselves for their roles as wives, mothers, and neighbours, and their confessions were deeply connected to their self-identity. ${ }^{4}$ According to Jackson, "[p] hysical and mental pressures explain to a certain degree why a substantial number of women accused of witchcraft made the confessions they did...[h]owever, this does not provide the whole picture." 5 Female witches were also the stereotypical opposite of good and an inversion of the traditional roles of women; they fought against male control by asserting their powers of witchcraft to gain independence and agency ${ }^{6}$ In Jackson's opinion witchcraft confessions were tied to the identity of a female and their struggles for self-identity in a society that was dominated and controlled by men. Women were forced to judge themselves and their

\footnotetext{
${ }^{1}$ Virginia Krause, “Confessional Fictions and Demonology in Renaissance France," Journal of Medieval \& Early Modern Studies 35, no.2 (2005): 335.

2 Krause, “Confessional Fiction,” 331 and 337.

3 Louise Jackson, “Witches, Wives and Mothers,” Women's History Review 4, no.1 (1995): 69.

4 Jackson, "Witches, Wives and Mothers," 64 and 80.

5 Jackson, "Witches, Wives and Mothers," 69.

6 Jackson, "Witches, Wives and Mothers," 72.
} 
behaviour within the confines of the established demonological narrative. ${ }^{7}$ Historians like Krause and Jackson have used trial records to find unique insights into the lives and rational of the victims of the witch trials through their confessions.

Historians have often turned to Germany as one of the key areas to explore trial records because of the vast number of trials and the widespread belief in witchcraft. In Germany there was no central legal authority, so princes had special powers, which enabled them to place witchcraft outside the ordinary legal system. ${ }^{8}$ Administrators were thus free from institutional restraints and were able to harshly prosecute the accused witches. There was a complete lack of discipline in some principalities as judges were hired with no legal training, and the citizens could overrule aspects of the legal system. ${ }^{9}$ The citizens were involved in the witch trials through both the persecution and prosecution of witches in their communities. A book that fundamentally demonstrates the nature of the German witch trials is The Trial of Tempel Anneke, Records of a Witchcraft Trial in Brunswick, Germany, 1663, which is a translated copy of the original trial. The trial itself occurred in Brunswick, a city located in the northern part of Germany between Hannover and Berlin that experienced numerous witch trials, the records of which were preserved in the local archives. ${ }^{10}$ In the seventeenth century it was a fortified, medium sized city, which was home to approximately 15,000 residents. ${ }^{11}$ It was a staunchly Lutheran city that was one of the first to join the Reformation in the 1520's. The citizens of Brunswick and the surrounding area were predominantly Protestant. The focus of this paper will be to analyze the confessions of Tempel Anneke, in an attempt to understand how her religious beliefs changed over the course of her trial. To complete this analysis, Anneke's interrogations will be studied in detail for her references to God, Jesus, and the sacraments. This paper will argue that Anneke's faith went through four distinct phases over the course of her trial due to the pressures she was experiencing from the magistrates and court officers.

Anna Roleffes was a Protestant woman locally known by the name of Anneke. She was a widow who lived on a farm in a small village called Harxbüttel located about seven kilometers northwest of Brunswick. ${ }^{12}$ The earliest written accusations of witchcraft against her are found in records dating from the summer of 1662 where it appears that her activities were being investigated. ${ }^{13}$ Anneke's trial officially began on 25 June 1663 with the accusation that she used sorcery to locate stolen goods, and her trial concluded on 30 December 1663 with her execution. ${ }^{14}$ From the witness testimonies gathered in the trial it

\footnotetext{
7 Jackson, “Witches, Wives and Mothers," 80.

8 Johannes Dillinger, “The Political Aspects of the German Witch Hunts," Magic, Ritual \& Witchcraft 4, no.1 (2009): 67.

9 Dillinger, "The Political Aspects," 68.

${ }^{10}$ Peter A. Morton ed., The Trial of Tempel Anneke: Records of a Witchcraft Trial in Brunswick, Germany, 1663, trans. Barbara Dähms (North York: University of Toronto Press, 2006): xiv.

${ }^{11}$ Morton, The Trial of Tempel Anneke, xiv.

12 Morton, The Trial of Tempel Anneke, xiii.

${ }^{13}$ Morton, The Trial of Tempel Anneke, xiii.

${ }^{14}$ Morton, The Trial of Tempel Anneke, xiii.
} 
can be deduced that Anneke worked in the village as a healer and diviner (a person who could uncover hidden information, like the location of lost items). ${ }^{15}$ The popular beliefs and common social characteristics of witches at this time in Europe were witches were typically women, widows, elderly, and largely dependent on their family. ${ }^{16}$ Anneke matched perfectly with all these characteristics, and she was consequently an easy target for people to accuse of witchcraft.

The first phase of faith in Anneke's trial was seen in its initial stages, where she claimed God would be her saviour and would unveil the truth to her accusers that she was innocent. Folio 3 was the first interrogation that consisted of a total of sixty-six questions ranging from questions about her childhood/background, religious knowledge, to questions that directly referred to the witness' accusations of witchcraft. Throughout the initial interrogation the judges were attempting to assess Anneke's likelihood of being a witch and whether she was capable of committing the magical acts witnesses accused her of. Anneke responded to the accusations and said, "God should save her" and "her dear Jesus Christ should save her from this."17 In the initial interrogation Anneke held her faith in God that her innocence would be proved and her trial would be stopped. She believed that her devotion and cries to God would make her accusers believe that she was a faithful Godfearing woman, who had not made a pact with the devil. She said "our Lord God would save her, they had been good friends all the days of their lives." ${ }^{18}$ She combatted the judges' questioning of her allegiance to God by reaffirming her devotion to Him and claiming she had "no business with the Evil Spirit."19 Anneke denied the allegations of the court officials and called on her love and loyalty to God to sway the officials of her innocence.

Anneke failed to pursued the judges of her innocence and in Folio 4, as in accordance with the law of the Carolina, the initial evidence brought forth by the witness testimony and the interrogation were enough to warrant a full criminal investigation. ${ }^{20}$ In Folio 6 the judges explored the discrepancies between the witnesses' testimonies under oath and Anneke's confessions. ${ }^{21}$ At this time, Anneke was under increased stress from the court officials to explain her actions and the inconsistencies with the witness statements. When her pleading to God had failed to stop her trial, Anneke changed strategies and attempted to defend the rational behind her actions. She endeavoured to justify her accused crimes by claiming they had been done in the name of God, and at this point she moved into her second phase of faith. In Folio 6, Anneke confessed that she had discovered who the thief was of Hans Tiehmann's stolen articles and was able to frighten him by preforming a series of actions, "in the name of God."22 This was in direct contradiction to her responses in Folio

\footnotetext{
${ }^{15}$ Morton, The Trial of Tempel Anneke, xiii.

${ }^{16}$ Morton, The Trial of Tempel Anneke, xiii-xiv.

${ }^{17}$ Morton, The Trial of Tempel Anneke, 21 and 23.

${ }^{18}$ Morton, The Trial of Tempel Anneke, 17.

${ }^{19}$ Morton, The Trial of Tempel Anneke, 23.

${ }^{20}$ Morton, The Trial of Tempel Anneke, 24.

${ }^{21}$ Morton, The Trial of Tempel Anneke, 27.

22 Morton, The Trial of Tempel Anneke, 28.
} 
3 , where she claimed she had done nothing to help find or frighten the thief, and instead merely gave Tiehmann information. ${ }^{23}$ Anneke, in her second phase of faith modified her confessions so they would correspond with the witnesses' sworn testimonies. She wanted to prove to the judges that she was innocent of colluding with the devil and was a loyal servant of God.

Anneke even went further to proclaim all the actions of witchcraft that she was accused of conducting had really been undertakings done in the name of God. In Folio 18 for example, in response to the judges question "Whether she didn't learn such things from the Evil Enemy", Anneke claimed, "ad proxe praecedentem Inquisitionalem ${ }^{24}$, and adds, that comes from God the Lord, that things are used. Must everything only come from the Evil Enemy."25 In Folio 20 Anneke also claimed that, "when you bury Christmas Rose and aloe in a small cloth in the name of God (emphasis added by author) under a house sill, so that it could not harden, a mandrake could not move away." 26 Through her testimony Anneke strove to justify her actions by claiming that God had sanctioned them, and that she was working to do good not evil. She was attempted to change the court officials and magistrates perception of her actions to help prove her virtue and sinlessness.

Anneke in the next stage of her trial returned to her previous phase of faith that God would save her and would not allow her to be falsely accused. In Folio 22, Anneke was once again interrogated and asked a series of forty-nine questions. When she was questioned about modifying a pear with witchcraft she stated that, "the almighty God shall save her from that, they have to prove that." ${ }^{27}$ She also affirmed that, "she didn't know the Devil, Jesus Christ may preserve us from that, surely they would not talk her neck away...our Lord God would give counsel."28 There was a sense of a growing escalation in frustration from both Anneke and her accusers on her unwillingness to confess to being a witch. Anneke at each question attempted to prove her innocence and fidelity with God, but no matter how many times she tried to reassure the judges she was innocent they continued to accuse her of witchcraft. The court officials and magistrates insisted as Krause explained on getting a confession that validated their narrative of devilish witches. ${ }^{29}$ The court officials refused to accept her testimony, and insisted that she was an evil witch in a pact with the devil. There was no attempt made by the officials to listen and judge fairly Anneke's responses, they would only accept answers that corresponded with their demonological narrative. Anneke tried to fight for her virtue by using her faith in God to craft her own narrative of her behaviour to demonstrate she was not a sinning heretic, but her arguments caught no traction with the court officials.

\footnotetext{
${ }^{23}$ Morton, The Trial of Temple Anneke, 16-17.

${ }^{24}$ In Folio 3 on page 21 she responded to the same question with silence.

${ }^{25}$ Morton, The Trial of Tempel Anneke, 59.

${ }^{26}$ Morton, The Trial of Tempel Anneke, 65.

27 Morton, The Trial of Tempel Anneke, 73.

${ }^{28}$ Morton, The Trial of Tempel Anneke, 76.

${ }^{29}$ Krause, “Confessional Fiction," 329.
} 
As the trial progressed and the interrogation sessions grew tenser with Anneke refusing to admit to witchcraft and an allegiance to the devil, the court officials turned to using the threat of torture. They used torture to intimidate her in the hope it would elicit a confession, causing her to move into her third phase in faith in which she called on God's judgement and mercy. Anneke at this point in her trial began to show her exasperation with the questioning and she fervently denied the accusations being thrust upon her. In the initial stages of questioning in Folio 26 where Anneke was questioned under the threat of torture, she "burst out angrily, and said: by the sacrament, what is she supposed to say, because she has nothing to do with the Devil." 30 The line of questioning was harsh and unrelenting because the officials were convinced that Anneke had consorted with the devil and further pressure and questioning would force her to confess. True to the officials belief as the menace of torture loomed close, Anneke eventually admitted she had worked with the devil. She confessed she had found the name of the thief by calling on the help of the devil, although she denied having a pact with him. ${ }^{31}$ After she had confessed to working with the devil Anneke became desperate for God's help to save her life. She called on "God in heaven to pity" and called "God have mercy." 32 She wanted to once again show her devotion towards God to the judges and reaffirm that even though she had consorted with the devil, God was still a prominent person in her life who she looked to for guidance. In this stage Anneke was still trying to earn favour not only with God, but also with the judges. She was trying to make them see her as a person who had had a lapse in judgement and had made a mistake but was trying valiantly to atone for what she had done by confessing her crimes. She wanted God and the officials to feel sorry for her and be more lenient in their sentencing of her crimes. When the threat of torture was introduced Anneke tried at first to maintain her innocence, but ultimately she faltered under the pressure and confessed to working with the devil. After she confessed to witchcraft she begged God to have sympathy for her, so that he could see and understand her plight.

In Folio 28 Anneke was subjected to questioning under torture, and at this point she moved into her final phase of faith. This phase of her faith consisted of her repenting for her sins and reconnecting with God because her pleads for mercy were no longer enough to compensate for the sins she confessed to. Under torture Anneke admitted to the crimes of witchcraft and disclosed she had made a pact with the devil. Anneke explained in her final response that "she promised herself to the same [devil] for 12 years, one is still missing, she to still wanted to stand by him for that time, after that she wanted to return to the dear God." 33 While enduring torture Anneke quickly confessed to all the accusations and crimes the officials had accused her of, but she retained at the end of her statement that she wanted to restore her relationship with God. Anneke confessed because, as Jackson explained, the physical pain she endured was too much, and she buckled under the pressure and perhaps she even believed to some extent that she was a 'bad' neighbour and

\footnotetext{
${ }^{30}$ Morton, The Trial of Tempel Anneke, 86.

31 Morton, The Trial of Tempel Anneke, 91.

32 Morton, The Trial of Tempel Anneke, 92-93.

33 Morton, The Trial of Temple Anneke, 105.
} 
mother who had worked with the devil. ${ }^{34}$ The crimes Anneke was accused of doing involved harming her neighbours and their animals through the use of herbs and ceremonies. Under torture her use of herbs and rituals changed from being done in the name of God to being done on behalf of the devil, which conformed to demonological beliefs repeatedly stated by the judges. Anneke confirmed the thesis of both Krause and Jackson, by acknowledging to the demonological narrative that validated the court officials' claims and she confessed to being a woman who defied the traditional female roles. Under torture Anneke was forced to assess and judge herself within the confines of the demonological theory in order to escape from the immeasurable pressure and pain of torture.

Anneke spent the remainder of her trial confessing and repenting for her sins, and pleading with the officials that God would show pity and forgive her sins, and therefore so should they. In Folio 29, Anneke was interrogated with the same questions as Folio 27, but without the use of torture, and the guilt she felt quickly became apparent. Anneke became desperate to prove to the officials how remorseful she was and asked for the forgiveness of her sins. In one of her answers, for example, she cried, "Dear God, dear God, what have I done."' 35 Johann Pilgram the court scribe in Folio 33 wrote, "[s]he behaved wretchedly, saying, there would be mercy with God and the authorities, they would be able to be merciful to her." ${ }^{36}$ She went further to say, "with God there is mercy, he would not leave her with Satan."'37 Anneke attempted to convince the officials that she had repented for her sins, and God would consequently forgive and protect her. She claimed that she had only hurt and never killed a person, and "God forgives murderers and manslaughterers their sins, he would forgive Inquisitin her sin as well." ${ }^{8}$ Anneke endeavoured to show that her sins were not unforgivable, and that God ultimately would forgive her for her sins no matter what the judges decided. It appeared that Anneke tried to rationalize with the judges that because God would forgive her crimes, so should the judges, and she should be left with a more lenient punishment than death. She also thanked God that she had been able to escape the devil and stated, "dear God will be merciful to her, that will be with her in life or in death. She thanks God that it came to this, and that she was brought to her repentance." ${ }^{39}$ Anneke explained to the court officials that she had repented, and God would forgive her no matter what the officials thought. Anneke tried to persuade the judges to let her live because she had deduced that God would forgive her sins and she would spend eternity with him in heaven. Therefore the judges should look to God as an example and forgive her sins and allow her to live. In her final interrogation in Folio 43 she stated, "Oh Lord Jesus Christ, stand by me and forgive all my sin."' 40 In the final phase of her faith, Anneke begged God and the judges to forgive her sins and made arguments that denoted to God's forgiving nature.

\footnotetext{
34 Jackson, "Witches, Wives and Mothers," 313 and 80.

${ }^{35}$ Morton, The Trial of Tempel Anneke, 109.

${ }^{36}$ Morton, The Trial of Tempel Anneke, 119.

${ }^{37}$ Morton, The Trial of Tempel Anneke, 120.

${ }^{38}$ Morton, The Trial of Tempel Anneke, 121.

${ }^{39}$ Morton, The Trial of Tempel Anneke, 121.

${ }^{40}$ Morton, The Trial of Tempel Anneke, 143.
} 
Anneke remained consistent with her confessions, and never ceased to give up her faith in God and her belief that her devotion would save her from death.

To conclude, under the immense and persistent pressures of the magistrates and court officials, Anneke progressed through four distinct phases in her faith and devotion to God. In the first phase God would be her saviour, in the second she claimed her actions were all done in the name of God, in the third phase God would be merciful, and in the final phase God would forgive her sins. As the officials' questioning and demands for a confession escalated Anneke used her answers as a time to express her faith and reverence to God. Anneke shifted her references to God as a way to rationalize and legitimize her actions initially, and prove her innocence later on. As the trial wore on and she admitted to more crimes and sins, her references to God turned to begging for mercy and forgiveness because she realized she was facing immanent death, and her only hope was to convince the judges she was a changed woman. Throughout the trial Anneke consistently brought up her faith because she believed it would save her life or in the last stages offer her eternity with God in heaven. The Trial of Tempel Anneke sheds light upon the dark history of the German witch trials, and the pain suffered by ordinary women like Tempel Anneke who were prosecuted as witches. Future research is necessary to determine whether the four phases of faith were an isolated occurrence in the trial of Tempel Anneke or whether it was a broader trend seen in other European witch trials. 
Primary Source:

Bibliography

Morton, Peter A. ed. The Trial of Tempel Anneke: Records of a Witchcraft Trial in Brunswick, Germany, 1663. Translated by Barbara Dähms. North York: University of Toronto Press, 2006.

Secondary Sources:

Dillinger, Johannes. "The Political Aspects of the German Witch Hunts." Magic, Ritual \& Witchcraft 4, no.1 (2009): 62-81.

Jackson, Louise. “Witches, Wives and Mothers.” Women's History Review 4, no.1 (1995): 6384.

Krause, Virginia. "Confessional Fictions and Demonology in Renaissance France." Journal of Medieval \& Early Modern Studies 35, no.2 (2005): 327-348. 